\title{
A COMPARATIVE STUDY OF PATIENTS' ATTITUDE TOWARDS INFORMED CONSENT IN PUBLIC AND PRIVATE HOSPITALS
}

\author{
Saadoun Faris Al Azmi', Bashair Abdullah Almutairi', Ahmad Mousa Al Jafar ${ }^{2}$ \\ ${ }^{1}$ Department of Medical Records, College of Health Sciences, Public Authority of Applied Education \\ and Training (PAAET), Kuwait \\ ${ }^{2}$ Department of Surgery, Adan Hospital, Ministry of Health, Kuwait
}

\section{ABSTRACT}

Background: Patient's autonomy is an imperative issue in the health service field. It is a known fact that patient's awareness and understanding of legal and ethical issues related to the consent process is often limited. Adequate information before a surgical procedure is fundamental to give informed consent. Information should include a description of the benefits, risks and complications of the intended procedure as well the alternative treatment options.

Objectives: The aim of this study was to compare patients in public and private hospitals of Kuwait as regards their understanding of legal implications, view-about the scope, value and function of consent form during the clinical practice.

Methods: A comparative descriptive cross-sectional survey was conducted in 6 public and 2 private hospitals from January to June 2016 in the state of Kuwait. A total of 910 patients aged 18 years old and above admitted to the surgery departments in the selected hospitals were invited. Structured self-administered questionnaires were distributed to the patients hospitalized in the selected departments of Kuwaiti hospitals. The questionnaire was pilot-tested prior to being finalized. Statistical analysis for the achieved data was done.

Results: Of 910 patients, $805(88.5 \%)$ completed the questionnaires. Patients in public hospitals were 584 $(72.5 \%)$ while those in private hospitals were $221(27.5 \%)$. Significantly higher proportion of patients in private hospitals were in the view that signing the consent form is a legal requirement $(88.7 \%)$. Significantly more private sector patients agreed that signing the consent form means that all exactly are present in the consent form (91.0\%), and the doctor cannot do anything different from what was on the form unless it is lifesaving (82.4\%). More patients in private sector hospitals agreed about the statements that the consent form made it clear what was going to happen (79.6\%) and the consent form gave the doctors control over what happened (72.9\%). There were no statistical significant differences observed between patients in the two disciplines as regards their responses to the statements: the consent form is important $(\mathrm{p}=0.167)$, the consent form made the patient aware of the risks of the operation $(\mathrm{p}=0.520)$, the consent form made the patient wishes known $(\mathrm{p}=0.393)$, the consent form prevents mix ups during the operation $(\mathrm{p}=0.470)$, the consent form was just another piece of paper $(p=0.361)$, the patient just signed the consent form so he/she could have the operation $(p=0.053)$ and signing the consent form was mainly to protect the hospital $(\mathrm{p}=0.049)$.

Conclusion: Patients in public and private hospitals have limited knowledge of the legal implications of signing or not signing consent forms, indicates that consenting in its current form is not informed and should be reassessed in order to achieve patient autonomy. The policy and decision makers need to develop educational program towards inform consent.

Keywords: Hospitals; Patients; Medical ethics; Informed Consent.

Correspondence to: Dr. Saadoun Al Azmi

Mobile: +965-99656756

E-mail : drsaadoun@yahoo.com; sf.alazmi@paaet.edu.com

\section{INTRODUCTION}

$I_{\text {nomers }}^{n}$ nformed consent is the process by which the treating health care provider discloses appropriate information to a competent patient so that the patient may make a voluntary choice to accept or refuse treatment (McCullough and Chervenak, 2007). The term «informed consent» recognizes not only the patients' autonomy in decision but also the right to complete information. The informed consent process requires the physician to explain in sufficient detail, the diagnostic, therapeutic and prognostic reasoning that leads to his expert decision on what is in the best interest of the patient. Paternalism and coercion are antithetical to the concept of informed consent (McCullough and Chervenak, 2007; Carmen and Joffe, 2005). Basic or simple consent entails letting the patient know 
what you would like to do; giving basic information about the procedure; and ensuring that the patient assents or consents to the intervention. Assent refers to a patient's willing acceptance of a treatment, intervention, or clinical care (Jessica De Bold, 2014). Informed consent is the permission or rejection of information presented in an open form and reflects the following: the nature of the proposed medical procedure, results, risks, benefits and side effects, alternative medical procedures and their character, results, risks, benefits and side effects, and the risks and benefits, including potential harm to health or danger to life of the patient (Appelbaum, 2007; Humayun et al., 2008). The principle of informed consent is often neglected during patient care in developing countries. In most cases, private and public hospitals in Kuwait have their own forms of informed consent. These forms are often in written form. However, most of patients get so little information through these forms. Patient awareness of their rights to informed consent is often low (Bhurgri and Qidwai, 2004; Khan, 2008). Mostly, the written forms are used in severe surgeries to inform patient about the risks and benefits, and also to have evidence that the patient signed this form voluntary and gives permission to the intervention to his/her body. However, in both type of hospitals (public and private) the oral form of informed consent is used mostly for basic treatment or examination (measuring blood pressure, giving blood tests, ultrasound scanning, needle injections, etc.) (Cohen and Ezer, 2016). Previous qualitative research has shown that a significant number of physicians do not think it is necessary to obtain a proper information to their patients (Jafarey and Farooqui, 2005). Furthermore, general observation points to wide differences between the qualities of medical care offered at private and public hospitals. In view of these observations, this study was conducted to assess and to explore the differences in patients' perceptions toward informed consent in public and private hospitals in the state of Kuwait.

\section{SUBJECTS AND METHODS}

A comparative descriptive cross-sectional survey was conducted from January to June 2016 in the state of Kuwait. All public general hospitals (n $=6$ ) and two private hospitals were randomly selected (out of 11 private hospitals) as research settings. The study population was patients 18 years old and above admitted to the surgery departments in the selected hospitals. Sample size for study participants was calculated by a web based freely accessible sample size calculator, Raosoft (Raosoft, 2013). Based on the formula for sample size calculation and margin of error from Raosoft, the estimated sample size for participants was for the recruitment of 910 participants. We excluded from the study patients not competent to sign their own consent for surgery, patients not speaking the selected languages of interview, those too ill to participate in the study and, obviously patients without a signed consent form for surgery in their files. Structured self-administered questionnaires were distributed to the patient hospitalized in surgery departments. In this study, a questionnaire was developed and handed out to patient who had just undergone surgery and who were counseled before their elective surgery and signed their consent forms. The questionnaire was derived from different published studies dealing with the same topic as well as from personal experience (Shiraz et al, 2005; Khan,2008; Humayun et al, 2008; and Saeed et al, 2011). It took 15-20minute to be filled. To increase the response rate repeated visits were sometimes necessary to collect completed questionnaire from the patients. The questionnaire consisted of four sections. The first section collected information on participants' demographic (age, gender, nationality, educational status and marital status). Second section included six statements addressing patient's understanding of the legal implications of signing the consent form. The third section included four statements regarding patient's views on the scope of the consent form. The fourth section included ten questions based on 3-likert type scale questions about patient's agreement with statements on the value and function of the consent form. Each question was varied in response from disagree, neutral and agree. The questionnaire was pilot tested by 30 patients prior to being finalized. The investigators reviewed feedback from the pilots, and, where appropriate, questions were modified accordingly. Description of qualitative variables was performed by comparing frequency tables and quantitative 
variables by calculation of mean \pm standard deviation. Qualitative variables were assessed using Chi square test. Statistical analysis was done using SPSS version 21. Confidence interval was $95 \%$ and $\mathrm{P}$ value $<0.05$ was regarded as significant. The reliability and validity of the questionnaire was assessed by calculating the correlation statistics for the intra-questionnaire groups of questions.

\section{ETHICAL CONSIDERATIONS}

Ethical review and approval was sought from the Research Ethical Committee of Kuwait Ministry of Health. Permission to conduct the study was obtained from the respective hospital administration selected. Informed verbal consent was obtained before recruitment of any participant into the study. Participant's identifying information was kept confidential. To maintain confidentiality, questionnaires were made anonymous.

\section{RESULTS}

Out of the total patients surveyed, 805 were included (response rate $88.5 \%$ ). Patients in public hospitals were $584(72.5 \%)$ while those in private hospitals were 221, 27.5\%. Background characteristics of hospitalized patients in public and private hospitals in Kuwait are summarized in Table (1). The mean age of patients in public hospitals was $36.4 \pm 13.3$ years. This was significantly older than that of patients in private sector hospitals $(33.5 \pm 9.1$ years $), \mathrm{p}=<0.001$. The highest proportions of patients in both public $(37.7 \%)$ and private $(59.7 \%)$ hospitals were in the age group $30-<40$ years. However, patients aged 40 years or older were significantly more encountered in public hospitals $(31.7 \%)$ as compared to $15.9 \%$ in private hospitals, $\mathrm{p}=$ $<0.001$. Most of patients in private sector hospitals were females $(62.0 \%)$ while $38.0 \%$ were males in comparison to $47.8 \%$ females and $52.2 \%$ males respectively in public sector hospitals. This difference was statistically significant, $\mathrm{p}=$ $<0.001$. Significantly higher proportion of Kuwaiti patients were in private hospitals $(68.8 \%)$ and $31.2 \%$ were non-Kuwaiti patients, (p $=<0.001)$. Below intermediate school educated patients were significantly more admitted to public hospitals $(25.3 \%$ versus $8.6 \%$ ) while above secondary educated patients were more in private hospitals $(60.6 \%$ versus $39.4 \%), p=<0.001$. No statistical significant difference was observed between patients in public and private hospitals as regards marital status, $\mathrm{p}=0.168$ Patients' understanding of the legal implications of signing the consent form in public and private hospitals in Kuwait was shown in table (2). Significantly higher proportions of patients in private hospitals agreed about the statements that signing the consent form is a legal requirement $(88.7 \%)$ and they have the right to change their mind after signing the consent form (68.8\%) as compared to $73.1 \%$ and $58.9 \%$ respectively in public hospitals, $\mathrm{p}=<0.001$ and 0.022. However, significantly higher proportions of patients in private hospitals wrongly agreed to the statements that signing the consent form removes their right to compensation (33.0\%), if the patient was not be able to sign the consent form, the operation cannot take place, even if this means that the

patient could die $(37.1 \%)$, and if the patient refused to sign the consent form the operation cannot take place even if this means he/she could die $(65.2 \%)$ as compared to $31.3 \%, 29.6 \%$ and $38.9 \%$ respectively in public hospitals, $\mathrm{p}=0.001$, 0.007 and $<0.001$.

Comparable proportions of patients in public (78.9\%) and private hospitals $(73.3 \%)$ agreed to the statement that if the patient can't sign the consent form, the next of kin can sign on behalf. Table (3) presents patients' views on the scope of the consent form in public and private hospitals of Kuwait. Significantly more patients in private sector hospitals were of the view that signing the consent form means that all exactly are present in the consent form $(91.0 \%)$, The doctor may do something different from what is on the form if he/she thinks it is best for the patient (71.0\%), and the doctor cannot do anything different from what was on the form unless it is life-saving $(82.4 \%)$ as compared to $84.2 \%, 59.9 \%$ and $65.8 \%$ of public hospitalized patients where $\mathrm{p}=0.038$, 0.007 , and $<0.001$ respectively. However, no statistical significant difference was noted between patients in public and those in private hospitals as regards their responses to the statement that they fully understood what was going to happen, $p=0.152$. Table (4) shows patient's views of the value and function of the consent form in public and private hospitals of Kuwait. Significantly higher proportions of 
patients in private sector hospitals agreed about the statements that the consent form made it clear what was going to happen $(79.6 \%)$ and the consent form gave the doctors control over what happened $(72.9 \%)$ as compared to $68.3 \%$ and $63.7 \%$ of patients in public hospitals where $\mathrm{p}=$ $<0.001$ and 0.049 respectively. On the other hand, significantly more patients in public hospitals wrongly agreed that signing the consent form was a waste of time $(21.6 \%$ versus $10.0 \%), \mathrm{p}=$ $<0.001$. There were no statistical significant differences observed between patients in the two disciplines as regards their responses to the statements the consent form is important $(\mathrm{p}=$ $0.167)$, the consent form made the patient aware of the risks of the operation $(\mathrm{p}=0.520)$, the consent form made the patient wishes known ( $\mathrm{p}=$ 0.393), the consent form prevents mix ups during the operation $(\mathrm{p}=0.470)$, the consent form was just another piece of paper $(\mathrm{p}=0.361)$, the patient just signed the consent form so he/she could have the operation $(\mathrm{p}=0.053)$ and signing the consent form was mainly to protect the hospital $(\mathrm{p}=$ 0.049).

Table 1. Characteristics of the selected hospitalized selected patients in public and private hospitals in the States of Kuwait

\begin{tabular}{|c|c|c|c|c|c|c|}
\hline & \multicolumn{6}{|c|}{ Hospital Type } \\
\hline Characteristics & \multicolumn{2}{|c|}{$\begin{array}{l}\text { Public } \\
(\mathrm{n}=584)\end{array}$} & \multicolumn{2}{|c|}{$\begin{array}{l}\text { Private } \\
(\mathbf{n}=\mathbf{2 2 1})\end{array}$} & \multirow[t]{2}{*}{ P Value } & \\
\hline No. & & & No. & $\%$ & & \\
\hline $\begin{array}{ll}\begin{array}{l}\text { Age } \\
\text { (years) }\end{array} & \text { group } \\
<30 & \\
<30\end{array}$ & 179 & 30.7 & $\overline{54}$ & 24.4 & $<0.001^{*}$ & \\
\hline $30-$ & 220 & 37.7 & 132 & 59.7 & & \\
\hline $40-$ & 99 & 17.0 & 30 & 13.6 & & \\
\hline$\overline{50+}$ & 86 & 14.7 & 5 & 2.3 & & \\
\hline $\begin{array}{l}\text { Mean } \pm \text { SD } \\
<0.001 *\end{array}$ & & & \pm 13. & & & $33.5 \pm 9.1$ \\
\hline \multicolumn{7}{|l|}{ Gender } \\
\hline Male & 305 & $\overline{52.2}$ & 84 & 38.0 & $<0.001 *$ & \\
\hline Female & 279 & 47.8 & 137 & 62.0 & & \\
\hline \multicolumn{7}{|l|}{ Nationality } \\
\hline Kuwaiti & 244 & 41.8 & 152 & 68.8 & $<0.001^{*}$ & \\
\hline Non-Kuwaiti & 340 & 58.2 & 69 & 31.2 & & \\
\hline \multicolumn{7}{|c|}{ Educational Status } \\
\hline $\begin{array}{l}\text { Below school } \\
\text { Intermediate }\end{array}$ & 148 & 25.3 & 19 & 8.6 & $<0.001^{*}$ & \\
\hline Secondary level & 206 & 35.3 & 68 & 30.8 & & \\
\hline Above secondary & 230 & 39.4 & 134 & 60.6 & & \\
\hline \multicolumn{7}{|l|}{ Marital status } \\
\hline Single & 120 & 20.5 & 48 & 68.8 & 0.168 & \\
\hline Married & 429 & 73.5 & 162 & 73.3 & & \\
\hline Divorced & 15 & 2.6 & 152 & 4.1 & & \\
\hline Widowed & 20 & 3.4 & 69 & 0.9 & & \\
\hline
\end{tabular}

$\mathrm{P}$ value of chi square test $*$ Significant at $<0.05$ level. 
Table 2. Patients understanding of the legal implications of signing the consent form in public and private hospitals of Kuwait

\begin{tabular}{|c|c|c|c|c|c|}
\hline Statements & $\begin{array}{l}\text { Hospital } \\
\text { type }\end{array}$ & $\begin{array}{l}\text { Agree } \\
(\%)\end{array}$ & $\begin{array}{l}\text { Disagre } \\
\text { e } \\
(\%)\end{array}$ & $\begin{array}{l}\text { Don't } \\
\text { know } \\
(\%)\end{array}$ & $\begin{array}{l}\mathbf{P} \\
\text { Value }\end{array}$ \\
\hline $\mathbf{N}$ & $\begin{array}{l}\text { Public (n584) } \\
\text { Private(n221) } \\
\end{array}$ & & & & \\
\hline $\begin{array}{l}\text { Signing the consent form is a legal } \\
\text { requirement }\end{array}$ & $\begin{array}{l}\text { Public } \\
\text { Private }\end{array}$ & $\begin{array}{l}73.1 \\
88.7 \\
\end{array}$ & $\begin{array}{l}12.8 \\
5.9\end{array}$ & $\begin{array}{l}14.0 \\
5.4\end{array}$ & $<0.001 *$ \\
\hline $\begin{array}{l}\text { \#Signing the consent form removes your } \\
\text { right to compensation }\end{array}$ & $\begin{array}{l}\text { Public } \\
\text { Private }\end{array}$ & $\begin{array}{l}31.3 \\
33.0\end{array}$ & $\begin{array}{l}47.6 \\
57.0\end{array}$ & $\begin{array}{l}21.1 \\
10.0\end{array}$ & $0.001 *$ \\
\hline $\begin{array}{l}\text { You have the right to change your mind } \\
\text { after signing the consent form }\end{array}$ & $\begin{array}{l}\text { Public } \\
\text { Private }\end{array}$ & $\begin{array}{l}58.9 \\
68.8 \\
\end{array}$ & $\begin{array}{l}20.2 \\
17.6\end{array}$ & $\begin{array}{l}20.9 \\
13.6\end{array}$ & $0.022 *$ \\
\hline $\begin{array}{l}\text { \# If you are not able to sign the consent } \\
\text { form, the operation cannot take place, } \\
\text { even if this means you could die }\end{array}$ & $\begin{array}{l}\text { Public } \\
\text { Private }\end{array}$ & $\begin{array}{l}29.6 \\
37.1\end{array}$ & $\begin{array}{l}46.2 \\
48.4\end{array}$ & $\begin{array}{l}24.1 \\
14.5\end{array}$ & $0.007 *$ \\
\hline $\begin{array}{l}\text { \#If you refuse to sign the consent form } \\
\text { the operation cannot take place even if } \\
\text { this mean you could die }\end{array}$ & $\begin{array}{l}\text { Public } \\
\text { Private }\end{array}$ & $\begin{array}{l}38.9 \\
65.2\end{array}$ & $\begin{array}{l}34.6 \\
21.7\end{array}$ & $\begin{array}{l}26.5 \\
13.1\end{array}$ & $<0.001 *$ \\
\hline $\begin{array}{l}\text { If you can't sign the consent form, your } \\
\text { next of kin can sign on your behalf }\end{array}$ & $\begin{array}{l}\text { Public } \\
\text { Private }\end{array}$ & $\begin{array}{l}78.9 \\
73.3\end{array}$ & $\begin{array}{l}11.8 \\
17.6\end{array}$ & $\begin{array}{l}9.2 \\
9.0\end{array}$ & .094 \\
\hline
\end{tabular}

Responses are expressed as percentages of patients who agreed about the statement

$\mathrm{P}$ value of Chi-square test, * Significant at $<0.05$ level

\# Negative questions

Table 3. Patient's views on the scope of the consent form in public and private hospitals of Kuwait

\begin{tabular}{|c|c|c|c|c|c|}
\hline Statements & $\begin{array}{l}\text { Hospital } \\
\text { type }\end{array}$ & $\begin{array}{l}\text { Agree } \\
(\%)\end{array}$ & $\begin{array}{l}\text { Disagre } \\
\text { e } \\
(\%)\end{array}$ & $\begin{array}{l}\text { Don't } \\
\text { know } \\
(\%) \\
\end{array}$ & $\begin{array}{l}\mathbf{P} \\
\text { Value }\end{array}$ \\
\hline $\mathbf{N}$ & $\begin{array}{l}\text { Public (n584) } \\
\text { Private(n221) }\end{array}$ & & & & \\
\hline $\begin{array}{l}\text { All exactly are present in the consent } \\
\text { form }\end{array}$ & $\begin{array}{l}\text { Public } \\
\text { Private }\end{array}$ & $\begin{array}{l}84.2 \\
91.0\end{array}$ & $\begin{array}{l}7.0 \\
5.0\end{array}$ & $\begin{array}{l}8.7 \\
4.1\end{array}$ & $0.038 *$ \\
\hline $\begin{array}{l}\text { The doctor may do something different } \\
\text { from what is one the form if he/she } \\
\text { thinks it best for me }\end{array}$ & $\begin{array}{l}\text { Public } \\
\text { Private }\end{array}$ & $\begin{array}{l}59.9 \\
71.0\end{array}$ & $\begin{array}{l}28.6 \\
23.1\end{array}$ & $\begin{array}{l}11.5 \\
5.9\end{array}$ & $0.007 *$ \\
\hline $\begin{array}{l}\text { The doctor cannot do any thing } \\
\text { different from what was on the form } \\
\text { unless it is life-saving }\end{array}$ & $\begin{array}{l}\text { Public } \\
\text { Private }\end{array}$ & $\begin{array}{l}65.8 \\
82.4\end{array}$ & $\begin{array}{l}21.6 \\
11.8\end{array}$ & $\begin{array}{l}12.7 \\
5.9\end{array}$ & $<0.001 *$ \\
\hline $\begin{array}{l}\text { I fully understood what was going to } \\
\text { happen }\end{array}$ & $\begin{array}{l}\text { Public } \\
\text { Private }\end{array}$ & $\begin{array}{l}73.8 \\
80.1\end{array}$ & $\begin{array}{l}15.1 \\
10.4\end{array}$ & $\begin{array}{l}11.1 \\
9.5\end{array}$ & 0.152 \\
\hline
\end{tabular}

Responses are expressed as percentages of patients who agreed about the statement.

$\mathrm{P}$ value of Chi-square test, * Significant at $<0.05$ level. 
Table 4. Patients' views of the value and function of consent form in public and private hospitals of Kuwait

\begin{tabular}{|c|c|c|c|c|c|}
\hline Statements & $\begin{array}{l}\text { Hospital } \\
\text { type }\end{array}$ & $\begin{array}{l}\text { Agree } \\
(\%)\end{array}$ & $\begin{array}{l}\text { Disag } \\
\text { ree } \\
(\%) \\
\end{array}$ & $\begin{array}{l}\text { Don't } \\
\text { know } \\
(\%)\end{array}$ & $\begin{array}{l}\mathbf{P} \\
\text { Value }\end{array}$ \\
\hline $\mathbf{N}$ & $\begin{array}{l}\text { Public (n584) } \\
\text { Private(n221) }\end{array}$ & & & & \\
\hline The consent form is important to me & $\begin{array}{l}\text { Public } \\
\text { Private }\end{array}$ & $\begin{array}{l}5.5 \\
3.2 \\
\end{array}$ & $\begin{array}{l}13.5 \\
10.4\end{array}$ & $\begin{array}{l}81.0 \\
86.4\end{array}$ & 0.167 \\
\hline $\begin{array}{l}\text { The consent form made it clear what } \\
\text { was going to happen }\end{array}$ & $\begin{array}{l}\text { Public } \\
\text { Private }\end{array}$ & $\begin{array}{l}17.3 \\
5.4\end{array}$ & $\begin{array}{l}14.4 \\
14.9\end{array}$ & $\begin{array}{l}68.3 \\
79.6\end{array}$ & $<0.001 *$ \\
\hline $\begin{array}{l}\text { The consent form made aware of the } \\
\text { risks of the operation }\end{array}$ & $\begin{array}{l}\text { Public } \\
\text { Private }\end{array}$ & $\begin{array}{l}15.2 \\
9.0\end{array}$ & $\begin{array}{l}16.3 \\
19.9\end{array}$ & $\begin{array}{l}68.5 \\
71.0\end{array}$ & 0.520 \\
\hline $\begin{array}{l}\text { The consent form made my wishes } \\
\text { known }\end{array}$ & $\begin{array}{l}\text { Public } \\
\text { Private }\end{array}$ & $\begin{array}{l}16.6 \\
17.6\end{array}$ & $\begin{array}{l}22.3 \\
26.2\end{array}$ & $\begin{array}{l}61.1 \\
56.1\end{array}$ & 0.393 \\
\hline $\begin{array}{l}\text { The consent form prevents mix ups } \\
\text { during the operation }\end{array}$ & $\begin{array}{l}\text { Public } \\
\text { Private }\end{array}$ & $\begin{array}{l}23.3 \\
22.6\end{array}$ & $\begin{array}{l}22.1 \\
18.6\end{array}$ & $\begin{array}{l}54.6 \\
58.8\end{array}$ & .475 \\
\hline $\begin{array}{l}\text { The consent form was just another } \\
\text { piece of paper }\end{array}$ & $\begin{array}{l}\text { Public } \\
\text { Private }\end{array}$ & $\begin{array}{l}57.4 \\
62.9\end{array}$ & $\begin{array}{l}17.0 \\
14.5\end{array}$ & $\begin{array}{l}25.7 \\
22.6\end{array}$ & 0.361 \\
\hline $\begin{array}{l}\text { I just signed the consent form so I } \\
\text { could have the operation }\end{array}$ & $\begin{array}{l}\text { Public } \\
\text { Private }\end{array}$ & $\begin{array}{l}20.9 \\
24.0\end{array}$ & $\begin{array}{l}18.8 \\
11.8\end{array}$ & $\begin{array}{l}60.3 \\
64.3\end{array}$ & 0.053 \\
\hline $\begin{array}{l}\text { Signing the consent form was } \\
\text { mainly to protect the hospital }\end{array}$ & $\begin{array}{l}\text { Public } \\
\text { Private }\end{array}$ & $\begin{array}{l}20.7 \\
18.1\end{array}$ & $\begin{array}{l}20.2 \\
19.9\end{array}$ & $\begin{array}{l}59.1 \\
62.0\end{array}$ & 0.675 \\
\hline $\begin{array}{l}\text { The consent form gave the doctors } \\
\text { control over what happened }\end{array}$ & $\begin{array}{l}\text { Public } \\
\text { Private }\end{array}$ & $\begin{array}{l}15.8 \\
12.2\end{array}$ & $\begin{array}{l}20.5 \\
14.9\end{array}$ & $\begin{array}{l}63.7 \\
72.9\end{array}$ & $0.049 *$ \\
\hline $\begin{array}{l}\text { Signing the consent form was a } \\
\text { waste of time }\end{array}$ & $\begin{array}{l}\text { Public } \\
\text { Private }\end{array}$ & $\begin{array}{l}65.1 \\
79.2\end{array}$ & $\begin{array}{l}13.4 \\
10.9\end{array}$ & $\begin{array}{l}21.6 \\
10.0\end{array}$ & $<0.001 *$ \\
\hline
\end{tabular}

Responses are expressed as percentages of patients who agreed about the statement.

$\mathrm{P}$ value of Chi-square test, * Significant at $<0.05$ level.

\section{DISCUSSION}

Although patients want to know their legal rights in hospital (Rajesh et al., 2013), there is a significant number of patients are unaware of, or misunderstand their ethical rights (Sankar et al., 2003). As compared to the private hospitals, the study has demonstrated the low level of understanding of informed consent process in public hospitals of Kuwait. It has shown the public perceptions of the consent form, and the advantage granted by the formal education in this regards. The discordance is higher in the public hospital and this may be directly related to the lower socioeconomic status of these patients compared to those in the private hospital.
Inconsistent with other study, our findings add to evidence showing that even when the consent process satisfies administrative and legal requirements, patients' needs may not be met, and some patients may even consent to surgery they do not want (Bhurgri and Qidwai, 2004). Regarding patient's understanding of the legal implications of signing the consent form, the present study depicted a significant higher proportions of patients from private compared to those in public hospitals were in the view that signing the consent form is a legal requirement although they have the right to change their mind after signing. In consistent, studies also revealed that most patients believed that the consent form was a legal document and they had to sign it, although most recognized 
that they could change their mind. The President's Commission had similar findings with $83.0 \%$ of patients considering that their signature on a consent form established agreement to treatment. They considered the consent form to be an official document (Making Health Care Decisions, 2009). Previously, Cassileth et al. (1980), reported that $80.0 \%$ of patients thought consent forms were necessary and more than $75.0 \%$ thought they were 'legal documents to protect physicians' rights' (Cassileth et al., 1980). Patients identified several important advantages of the consent process, however, there was substantial uncertainty of public sector patients about the implications of signing or not signing the consent form, including uncertainty about whether surgery can proceed in the absence of written consent, and rights to compensation. The present study revealed a significant higher proportion of patients from private compared to public hospitals do not believe that signing the consent form removes their right to compensation, also they thought that if they are not able to sign the consent form, the operation cannot take place, even if this means they could die. This in agreement with other studies (Humayun et al., 2008; Qidwai et al., 2013). Their patients thought that signing the consent form primarily signified agreement to have their operation. Smaller proportions thought they were either confirming that an explanation had been given or that the form primarily provided medico-legal protection for the doctor; however, half the group thought there was a medico-legal element to informed consent. In the present study, patients in private sector hospitals more significantly believed that doctor may do something different from what is in the consent form. One of reasons behind such practice is that the cultural trends in Kuwait still tend to accept the paternalistic model of medical care. This is in line with the Arab culture where the decision-making is often left purely to the doctors or other family members. In a study by Yousaf et al, (2007) $65 \%$ physicians in Kashmir and 35\% physicians in Malaysia said they would listen to the family's request to withhold information from the patient (Yousaf et al., 2007). A study from Hong Kong also revealed that the doctors and patients were more willing to accept the role of families in important decisions regarding medical care (Chan, 2004).

Though many patients in both disciplines saw that written consent as functioning primarily in their interests, however it is not a way of making their wishes known. A lack of awareness of the limits and scope of consent is clearly undesirable, potentially causing patients to feel disempowered and lacking in control. In the current study, many patients believed that by signing the consent form, they fully understood what was going to happen. Our study showed that compared to the public hospital, more patients in the private hospital believed that by signing the consent form, this gives the doctors control over what happened. Studies from Japan and Kashmir reflect similar views wherein patients are willing to accept what physicians choose for them, while physicians are satisfied with their role of a decision-maker (Humayun et al., 2008; Miyashita et al., 2006; Asai et al., 1998). In fact, most patients are happy to let treating doctors decide their treatment, but once this is done it is easy to give little information either to prevent making patients more anxious or because there is little time available in a busy clinic (Making Health Care Decisions, 2009; Cassileth et al., 1980; Patrick and Dawes, 1994). Adequate information provision has broad benefits of clinical consent form for patients. These include increased satisfaction, reduced emotional distress, and reduced use of analgesia underlining the importance of effective measures to improve patient education (Kinnersley et al., 2013).

In the present study, patient's agreement with statements on the value and function of the consent form, more patients from private sector hospitals perceived more benefits for the clinical consent form. As compared to public hospitalized patients, higher proportions of patient's from private hospitals agree that the consent form is important to them, the consent 
form made it clear what was going to happen, the consent form made them aware of the risks of the operation, the consent form prevents mix ups during the operation, they just signed the consent form so they could have the operation, signing the consent form was mainly to protect the hospital and the consent form gave the doctors control over what happened. However, they disagree that the consent form was just another piece of paper and signing the consent form was a waste of time. In the present study, patients in private and public hospitals similarly misperceived that signing the consent form was mainly to protect the hospital. Studies indicated that some patients receiving elective surgical procedures do not receive adequate information, the information is not fully understandable or the information patients receive is not tailored to their particular needs (Schattner et al., 2006). When eliciting informed consent, clinicians tend to focus on communicating the specific technical risks relating to the planned procedure (Barkin et al., 2009). Whilst these risks may be of shared interest between surgeon and patient, other factors relating to consequences of a procedure such as pain, length of stay in hospital and time off work after the operation are often overlooked. This leaves many patients with the opinion that the primary function of the consent form is to protect the hospital, rather than prepare the patient for the operation (Akkad et al., 2006).

Patients are often left to discover their postoperative course in the days following their procedure rather than at the time of considering whether to proceed with the operation (Fraval et al., 2015). This is a significant number of public hospitalized patients are unaware of, or misunderstand their ethical rights. This may be directly related to the lower socioeconomic status of these patients compared to those in the private hospital. The data of the current study showed that, overall, the views and understanding of informed consent was better at the private hospitals as compared to public hospitals. Doctors at private hospitals are better paid than their colleagues in the public-sector, something that may translate into better performance in transferring of information and greater care and satisfaction of the patients. Hence doctors in the private sector are more likely to respect the patients' fundamental rights related to their medical management.

Furthermore, significant patient burden at public hospitals often makes it impossible for the doctors to follow the full protocol of informed consent and, even doctors who favor practices like informed consent, often abandon these practices since they believe that most of their patients are uneducated and would not be able to decide what is best for them. It is also true though, that often the patients do not want to take any decision and want the doctor to decide each and everything for them. The results of this study need to be considered in the context of limitations. Self-administered questionnaire based survey was used for data collection rather than observation of the services in the wards in order to evaluate their quality. Nevertheless, we assume that it is helpful to document the implementation of patients' rights in public and private sector hospitals.

\section{CONCLUSION AND RECOMMENDATIONS}

The study concludes that there exists a vast discrepancy between the informed consent that perceived by patients in public and private sector hospitals in the state of Kuwait. The difference in perception and limited knowledge of the legal implications of signing or not signing consent form indicates that consenting in its current form is not informed and should be reassessed in order to achieve patient autonomy. The findings of this study are expected to assist the public and private hospitals' towards simplified and make inform consent easy to understand for the patients'. Moreover, the finding will be importance to policy and decision makers to develop educational program towards inform consent. 


\section{LIMITATION OF STUDY}

Oil company hospital (Al-Ahmadi) was excluded a mixed nature between public and private sectors. Formalities to get the approval to perform a research in the Private sector is a little bit difficult. This added another dimension for justification to select two out of 11 private hospitals, although the main reason was the proportion of hospital discharges of public and private sector in 2015. This proportion was almost $2 / 1$ or $162266 / 93049$.

\section{REFERENCES}

1. Akkad A, Jackson C, Kenyon S, Dixon-Woods M, Taub N, Habiba M (2006). Patients' perceptions of written consent: questionnaire study. BMJ.; 333:528

2. Appelbaum PS (2007). Assessment of patient's competence to consent to treatment. New England Journal of Medicine. ;357:1834-1840.

3. Asai A, Kishino M, Tsuguya F, Sakai M, Yokota M, Nakata K, Sasakabe S, Sawada K, Kaiji F (1998). A report from Japan: choices of Japanese patients in the face of disagreement. Bioethics., 12: 16272.

4. Barkin JS, Aronson JK, Feldman LS, Maddern GJ, Strasberg SM (2009). Evaluation and stages of surgical innovations. Lancet; 374:1089-96.

5. Bhurgri H, Qidwai W (2004). Awareness of the process of informed consent among family practice patients in Karachi. J Pak Med Assoc. ;54:398-401.

6. Carmen MG, Joffe S (2005). Informed consent for medical treatment and research: a review. Oncologist.; 10:636-41.

7. Cassileth BR, Zupkis RV, Sutton-Smith, March V (1980). Informed consent - why are its goals imperfectly realised? N Engl J Med; 302:896-900.

8. Chan HM (2004). Informed consent Hong Kong style: an instance of moderate familism. J Med Philos., 29: 195-206.

9. Cohen J, Ezer T. (2013). Human rights in patient care: a theoretical and practical framework. health and human rights, 15(2), 719.

10. Fraval A, Chandrananth J, Chong YM, Tran P, Coventry LS (2015). Internet based patient education improves informed consent for elective orthopaedic surgery: a randomized controlled trial. Fraval et al. BMC Musculoskeletal Disorders; 16:14

11. Humayun, A., Fatima, N., Naqqash, S., Hussain, S., Rasheed, A., Imtiaz, H., \& Imam, S. Z. (2008). Patients' perception and actual practice of informed consent, privacy and confidentiality in general medical outpatient departments of two tertiary care hospitals of Lahore. BMC Medical Ethics, 9, Article ID 14. http://dx.doi.org/10.1186/1472-6939-9-14

12. Jafarey AM, Farooqui A (2005). Informed consent in the Pakistani milieu: the physician's perspective. J Med Ethics; 31:93- 96.

13. Jessica De Bold (2014). Ethics in Medicine, University of Washington School of Medicine, Informed Consent.[https://depts.washingto n.edu/bioethx/topics/consent.html].

14. Khan RI (2008). Informed consent and some of its problems in Pakistan. J Pak Med Assoc. ;58:82-4.

15. Kinnersley P, Phillips K, Savage K, Kelly MJ, Farrell E, Morgan B, et al. (2013). Interventions to promote informed consent for patients undergoing surgical and other invasive healthcare procedures. Cochrane Database Syst Rev; 7:440-5.

16. Making Health Care Decisions (2009). The Ethical and Legal Implications of Informed Consent in the Patient - Practitioner Relationship, Vol 2, Appendices: Empirical studies of informed consent. Washington: U.S. Government Printing Office.

17. McCullough LB, Chervenak FA (2007). Informed consent. Clin Perinatol.; 34:275-85.

18. Miyashita M, Hashimoto S, Kawa M, Shima Y, Kawagoe H, Hase T, Shinjo Y, Suemasu K (2006). Attitudes toward disease and prognosis disclosure and decision making for terminally ill patients in Japan, based on a nationwide random sampling survey of the general population and medical practitioners. Palliat Support Care., 4: 389-98.

19. Patrick JD, Dawes BS (1994). FRCS' Pauline Davison SRN2. Informed consent: what do patients want to know? Journal of the Royal Society of Medicine;(8);149.

20. Qidwai W, Tabassum R, Khan FH, Javed S, Ali SM, Nanji K (2013). Informed consent, privacy and confidentiality practiced by doctors of a tertiary care hospital in a developing country. Indian J Med Ethics;10 (1):36-40. 
21. Rajesh DR, Singh A, Chopra M, Singh GP, Venkteshan M, Bhardwaj A et al. (2013). Patient's Awareness, Attitude, Understanding and Perceptions towards Legal Nature of Informed Consent. Indian Acad Forensic Med. ;35(1): 40-3.

22. Raosoft (2013). Accessed September 14,2013,[http://www.rao soft.com/samplesize.html]

23. Saeed N, Mushtaq A, Ahmed S (2011) Level of Understanding in Surgical Patients Undergoing Operative Procedures. Pak J Med Health Sci.; 5(3): 457-459

24. Sankar P, Mora S, Merz JF, Jones NL (2003). Patient perspectives of medical confidentiality: a review of the literature. J Gen Intern Med.; 18: 659-69.
25. Schattner A, Bronstein A, Jellin N (2006). Information and shared decision-making are top patients' priorities. BMC Health Serv Res.; 6:21.

26. Shiraz B, Shamim MS, Ahmed A. (2005). Medical ethics in surgical wards: Knowledge, attitude and practice of surgical team members in Karachi. Indian journal of medical ethics, 2(3), 94-96.

27. Yousaf RM, Fauzi ARM, How SH, Rasool AG, Rohana K (2007). Awareness, knowledge and attitude towards informed consent among doctors in two different cultures in Asia: a cross sectional comparative study in Malaysia and Kashmir, India. Singapore Med J., 48: 55965. 